\title{
A case-control study of Dietary Approaches to Stop Hypertension (DASH) diets, colorectal cancer and adenomas among Iranian population
}

\author{
Saeede Jafari Nasab ${ }^{1}$, Matin Ghanavati ${ }^{2}$, Pegah Rafiee ${ }^{2}$, Alireza Bahrami ${ }^{2}$, Nazanin Majidii, Cain C. T. Clark ${ }^{4}$,
} Amir Sadeghi ${ }^{5}$, Mohammad Houshyari ${ }^{6}$ and Ehsan Hejazi ${ }^{2^{*}}$

\begin{abstract}
Background and aims: Colorectal cancer (CRC) is the third most common cancer, worldwide. Recently, much attention has been given to the association between Dietary Approaches to Stop Hypertension (DASH) and CRC, however, data on colorectal adenomas (CRAs) as its precursor are scarce. Thus, the purpose of this case-control study was to investigate the association of DASH score with the risk of CRC and CRA in Iranian adults.

Method: A total of 499 participants, including 129 CRC and 130 CRA cases, along with 240 controls, were asked about their dietary intake via a validated questionnaire. The DASH score was then calculated based on a priori methods and categorized in quartiles. Multivariate logistic regression was performed to assess the association of DASH score and the risk of CRC and CRA.

Results: After adjusting for confounding variables, adherence to the DASH diet was associated with a reduction in the risk of CRC and CRA, respectively (OR of 4th versus 1st quartile $=0.04,95 \% \mathrm{Cl}: 0.01-0.11, \mathrm{OR}=0.10,95 \%$ Cl: $0.04-$ 0.22). Also, subgroup analysis based on gender showed that women and men with a higher DASH score had a significantly lower risk of CRC and CRAs.
\end{abstract}

Conclusion: The results of this study demonstrated that adherence to a DASH dietary pattern could reduce the risk of CRC and CRA in men and women. Promoting a DASH eating plan can be helpful in reducing the risk of CRC.

Keywords: Colorectal cancer, Colorectal adenomas, Adenomatous polyps, Dietary approaches to stop hypertension, DASH score, Dietary indexes, Diet quality indexes

\section{Background}

Colorectal cancer $(\mathrm{CRC})$ is the third most common cancer worldwide, and was recently estimated to be responsible for 694,000 deaths globally [1]. The distribution of CRC incidence varies by country, with the highest rates

\footnotetext{
* Correspondence: ehsanhejazi@gmail.com

${ }^{2}$ Department of Clinical Nutrition and Dietetics, Faculty of Nutrition Sciences and Food Technology, National Nutrition and Food Technology, Research Institute, Shahid Beheshti University of Medical Sciences, Tehran, Iran Full list of author information is available at the end of the article
}

in well developed countries [2]. However, recent lifestyle changes in less developed countries have elicited a rapid rise of CRC incidence in these countries. Indeed, CRC is the fourth most common cancer in Iran and its' incidence has been increasing during the past decade [3].

Inflammatory bowel disease, age, smoking, physical activity, obesity, and diet are well known risk factors of CRC $[4,5]$. Also, the vast majority of CRCs arise from colorectal adenomas (CRAs); these are benign lesions that take approximately 10 years to become cancerous

(c) The Author(s). 2021 Open Access This article is licensed under a Creative Commons Attribution 4.0 International License, which permits use, sharing, adaptation, distribution and reproduction in any medium or format, as long as you give appropriate credit to the original author(s) and the source, provide a link to the Creative Commons licence, and indicate if changes were made. The images or other third party material in this article are included in the article's Creative Commons licence, unless indicated otherwise in a credit line to the material. If material is not included in the article's Creative Commons licence and your intended use is not permitted by statutory regulation or exceeds the permitted use, you will need to obtain permission directly from the copyright holder. To view a copy of this licence, visit http://creativecommons.org/licenses/by/4.0/. The Creative Commons Public Domain Dedication waiver (http://creativecommons.org/publicdomain/zero/1.0/) applies to the data made available in this article, unless otherwise stated in a credit line to the data. 
and people with history of adenomas are at an increased risk of CRC [6].

Among modifiable risk factors of $\mathrm{CRC}$, diet has gained much attention [7]; indeed, with the goal of reducing disease risk and preventing chronic disease, including cancers, several dietary recommendations and patterns have been advocated [8,9]. Moreover, various scoring systems, such as Healthy Eating Index, Dietary Approaches to Stop Hypertension (DASH), and Mediterranean Style Dietary Pattern Score have been used to evaluate the adherence of populations to those dietary recommendations [10-12].

DASH is a dietary pattern, rich in fruits, vegetables, nuts, seeds, whole grain cereals, moderate in low-fat dairies, and low in sodium and added sugars. It was initially developed for management of high blood pressure $[13,14]$; yet, in addition to blood pressure, some studies have shown an association between the DASH dietary pattern and lower incidence of other chronic disease, such as cancers $[15,16]$. Although several, individual, components of DASH dietary pattern are associated with a reduced risk of CRC (whole grains, dairy product and lower amount of red meat, sodium and extra sugar) and CRA (red meat and extra carbohydrate), this association has not been affirmed for all components of this dietary pattern [17-21]. Accordingly, rather than concentrating on single foods and nutrients, utilization of the whole DASH plan in investigating diet-CRA- CRC relations can be beneficial [14]. Indeed, some studies have reported an inverse association between adherence to the DASH pattern and CRC $[22,23]$, and two studies have shown this association with CRA [24, 25].

Previous studies have principally focused on CRC, however, data pertaining to CRA are sparse. Also, to the best of our knowledge, data about the relationship between DASH pattern adherence and CRC and CRA are predominantly confined to western countries, with scant evidence from less developed countries, such as Iran. Therefore, the objective of this study was to determine whether DASH dietary pattern adherence is associated with CRC and CRA, as a precursor of CRC, in a casecontrol study of Iranian adults.

\section{Method}

\section{Study design and population}

This hospital-based case-control study was conducted in 3 major referral hospital (Taleghani, Shohadae Tajrish and Emam Hosein). The study participants had already been recruited for another study [26]. Briefly, CRC and CRA cases were patients with colonoscopy and histologically confirmed CRC and CRA, aged 30-79, with no history of cancers, polyps and inflammatory bowel diseases (IBD), and diagnosed in the preceding 3 months before the interview. Over the same period of time, controls were assigned randomly from patients admitted to the same hospitals for a wide spectrum of diseases other than cancers and polyps and IBD and did not follow any special diet. Controls were frequency-matched with cases by sex and age (10-year groups) and they were aged 30-79y. After exclusion of subjects with incomplete food frequency questionnaire (FFQ) and implausible energy intake estimates (outside the range of \pm 3 standard deviation from the mean), 499 participants ( 240 controls, 129 CRC and 130 CRAs) were included in the analysis. Informed consent was provided by all of the participants. Study protocol was approved by the ethics Committee of Shahid Beheshti University of Medical Sciences.

\section{Dietary assessment}

In this study, usual dietary intake of participants one year before diagnosis of diseases in cases, and one year prior to interview in controls was assessed through a valid and reliable semi-quantitative food frequency questionnaire, consisting of 148 foods and beverages [27]. For each item, participant were asked to specify how often (daily, weekly and monthly) they consumed foods based on a standard serving size. Then reported intakes were converted to weight equivalent (i.e. g, mg) per day. Energy and nutrients intake were estimated using United States Department of Agriculture (USDA) food composition table. However, for some traditional Iranian foods, such as traditional bread, the Iranian food composition table was used [28].

\section{Calculation of DASH score}

The method introduced by Fung [29] was used to measure dietary DASH score. Initially, to undo the effect of individual energy intake on the components of the DASH score, each food group intake was calculated per $1000 \mathrm{kcal}$. Then, participants were classified into quintiles and energy adjusted intake of 8 food groups and nutrients including fruits, vegetables, nuts and seeds and legumes, low-fat dairy products, whole grains which are targeted in the DASH score (adequacy components) and sodium, sweetened beverages, and red and processed meat which are minimized in DASH score (moderation components), were calculated. Individuals in highest quintiles of 5 adequacy components received 5 points and those in the lowest quintiles received minimum score of 1 . Regarding the intakes of moderation components, participants in the lower quintiles of intakes scored higher points (i.e., the lowest quintiles are assigned 5 points and the highest quintiles, 1 point). Finally. The total DASH score (ranged from 8 to 40) was provided by summing up the scores of 8 components for each individual. 


\section{Covariates' assessment}

In addition to dietary assessment, necessary information about sociodemographic, characteristics, family history of CRC and other cancers, smoking habit, medical history (comorbidities, medications, and vitamin/mineral supplements intake), and usual cooking techniques were asked in a face-to-face interview. Height and weight were measured to the closest $0.1 \mathrm{~cm}$ and $100 \mathrm{~g}$, respectively. Furthermore, physical activity was assessed by a validated questionnaire [30].

\section{Statistical analysis}

SPSS version 21.0 (SPSS Inc., Chicago, IL, 113 USA) was used to conduct Statistical analyses. Data were analyzed for normality using the Kolmogorov-Smirnov test, and are showed as means \pm SD (for normally distributed data) or median and interquartile range (for nonnormally distributed data). The differences between participants across the quartiles of energy-adjusted DASH score were compared using analysis of variance (ANOVA) or Kruskal-Wallis test (Kruskal-Wallis test used for non-normally distributed data) and the chisquare tests for quantitative variables and qualitative variables, respectively. Dietary DASH score was categorized into 4 quartiles based on the distribution among controls. Binary logistic regression was applied to estimate odds ratios (ORs) and 95\% confidence intervals for quartiles of DASH score. BMI $(\mathrm{kg} / \mathrm{m} 2)$, age (year), alcohol consumption, physical activity (MET), and history of diabetes, Coronary heart disease (CHD) and hypertension, family history of cancer were considered as potential confounders and were included in the models. The $p$-value of $<0.05$ was considered statistically significant and all reported $p$-values are two-tailed.

\section{Results}

Table 1 demonstrates the main characteristic of cases and controls. There was no statistically significant difference among participants (cancers and controls, adenomas and controls) in relation to BMI, family history of colorectal cancer in first-degree relatives, smoking status, vitamin D supplement, multivitamin use and energy intake. However, family history of cancer in first-degree relatives of CRC cases was higher than controls $(51.2 \%$ versus $32.9 \%$; $p$-value $<0.01$ ). Compared to controls, having at least one comorbidity such as diabetes was seen more in adenoma cases (36.9\% versus 15.8\%; $p$-value< 0.01 ) and the calcium supplement consumption was higher in adenoma cases than controls $(24.6 \%$ versus 14.6; $p$-value $=0.01$ ). Besides, the median value for physical activity was significantly higher in controls than adenomas [39.02 (36.51-41.33) vs. 37.75(34.67-40.40); $p$ value $<0.01]$. Controls had lower intake of salt compared to $\mathrm{CRC}$ and CRA cases ( $\mathrm{p}$-value $=0.002$ ). Common ways of cooking among controls differed significantly from cancer and adenomas patients, ( $\mathrm{p}$-value $<0.05)$. In details, cancer cases consumed more grilled and fried foods compare to controls and steamed food was consumed lower in adenomas than in controls.

Table 2 shows the distribution of participants in DASH score quartiles, according to main characteristics. Participants in the highest DASH quartile had lower sodium intake $(p<0.001)$ and were older $(58.19$ vs $54.29 \mathrm{y}$, $p=0.002$ ) compared to the lowest quartile.

Energy-adjusted DASH score and DASH score components are shown in Table 3. Compared to control group, patients with CRC and CRAs had significantly lower DASH score $(21,22$ vs 27, $p<0.001)$. Patients in both CRA and CRC groups ate less servings of vegetables, fruits, whole grains and nuts, legumes, and seeds than the control group $(p<0.01)$. The consumption of sodium, red and processed meats, and sweetened beverages were significantly higher in CRC and CRA groups compared to the control group.

Crude and multi-variable adjusted ORs and $95 \%$ confidence interval for risk of CRC and CRA, based on quartile of energy-adjusted DASH score, are provided in Table 4. We found that patients in highest quartile of DASH score had a significant reduction in the risk of both CRC and CRA vs. the lowest quartile. After adjusting for confounding variables, including BMI $\left(\mathrm{kg} / \mathrm{m}^{2}\right)$, age (year), alcohol consumption, physical activity (MET), history of diabetes, $\mathrm{CHD}$ and hypertension and family history of cancer, adherence to the DASH diet was associated with a reduction in the risk of CRC and CRA, respectively (OR $=0.04,95 \%$ CI: $0.01-0.11, \mathrm{OR}=0.10,95 \%$ CI: 0.04-0.22). Also, subgroup analysis based on gender showed that both women and men with higher DASH scores had significantly lower risk of CRC and CRAs.

\section{Discussion}

In this case-control study of Iranian men and women, we observed that a higher DASH score was associated with a reduced risk of CRC and CRAs in Iranian adults. In addition, this association was seen in subgroup analysis based on gender, where a higher DASH score was related to lower risk of both CRC and CRA in men and women.

The findings of our study are in line with some other studies that displayed an inverse relationship between DASH score and the risk of CRC [22, 31] and CRAs [24, 25]. Indeed, considering studies that performed sexspecific analysis, four studies showed a significant inverse association between higher DASH scores and CRC risk only in men [31-33] and one study only in women [34]. However, another study reported this relationship was present only in women, where the authors noted a reduced risk of CRC in higher quartiles of DASH score 
Table 1 The main characteristics of the cases and controls

\begin{tabular}{|c|c|c|c|c|c|}
\hline Variables & Controls $(n=240)$ & Cancers $(n=129)$ & Adenomas $(n=130)$ & $P$-value ${ }^{f}$ & $P$-value ${ }^{\dagger}$ \\
\hline Age (years) & $56(50-61.75)$ & $59(49.25-64)$ & $58(51-64)$ & $\neq$ & $\neq$ \\
\hline Gender (male) & $133(55.4)$ & $66(51.2)$ & $59(45.4)$ & $\ddagger$ & $\neq$ \\
\hline BMI (kg/m2) & $26.53(24.10-29.40)$ & $25.70(23.08-29.74)$ & $26.79(23.86-29.40)$ & 0.23 & 0.95 \\
\hline Smoking (yes) & $42(17.5)$ & $26(20.2)$ & $27(20.8)$ & 0.53 & 0.11 \\
\hline Comorbidities (yes) ${ }^{¥}$ & $38(15.8)$ & $17(13.2)$ & $48(36.9)$ & 0.84 & $0.002^{* *}$ \\
\hline Diabetes (yes) & $20(8.3)$ & $12(9.3)$ & $12(9.2)$ & 0.75 & 0.77 \\
\hline Hypertension (yes) & $13(5.4)$ & $4(3.1)$ & $23(17.7)$ & 0.34 & $0.01^{* *}$ \\
\hline Coronary Heart diseases (yes) & $5(2.1)$ & $1(0.8)$ & $13(10.0)$ & 0.31 & $0.00^{* * *}$ \\
\hline $\begin{array}{l}\text { Family history of cancer in first } \\
\text { degree (yes) }\end{array}$ & 89 (32.9) & $66(51.2)$ & $48(36.9)$ & $0.001^{* *}$ & 0.43 \\
\hline $\begin{array}{l}\text { Colorectal cancer family history } \\
\text { in first degree relatives (yes) }\end{array}$ & $18(7.5)$ & $10(7.8)$ & $17(13.1)$ & 0.15 & 0.08 \\
\hline \multicolumn{6}{|l|}{ Common ways of cooking food } \\
\hline Fried & $55(22.9)$ & $40(31)$ & $18(13.8)$ & $0.001^{* *}$ & 0.06 \\
\hline Boiled & $81(33.8)$ & $41(31.8)$ & $34(26.2)$ & 0.75 & 0.82 \\
\hline Grilled & $5(2.1)$ & $0(0)$ & $4(3.1)$ & $0.02^{* *}$ & 0.52 \\
\hline Steam cook & $3(1.3)$ & $2(1.6)$ & $0(0)$ & 0.32 & $0.006^{* *}$ \\
\hline Combined & $96(40)$ & $46(35.7)$ & $74(56.9)$ & $0.001^{* *}$ & 0.06 \\
\hline \multicolumn{6}{|l|}{ Level of salt intake } \\
\hline Low & $127(52.9)$ & $44(34.1)$ & $44(34.1)$ & $0.002^{* *}$ & $0.002^{* *}$ \\
\hline Normal & 79 (32.9) & $64(49.6)$ & $64(49.6)$ & 0.08 & 0.08 \\
\hline High & $34(14.2)$ & $21(16.3)$ & $21(16.3)$ & 0.07 & 0.07 \\
\hline Physical activity (MET/h/day) & $39.02(36.51-41.33)$ & $39.30(37.17-40.90)$ & $37.75(34.67-40.40)$ & 0.85 & $0.003^{*}$ \\
\hline $\begin{array}{l}\text { Monthly intake of } 50,000 \text { IU Vitamin } \\
\text { D supplement (yes) }\end{array}$ & $56(23.3)$ & $28(21.7)$ & $40(30.8)$ & 0.72 & 0.11 \\
\hline $\begin{array}{l}\text { Daily intake of } 500 \text { mg Calcium } \\
\text { supplement (yes) }\end{array}$ & $35(14.6)$ & $28(21.7)$ & $32(24.6)$ & 0.08 & $0.01^{* *}$ \\
\hline Multivitamin use every day (yes) & $18(7.5)$ & $16(12.4)$ & $9(7)$ & 0.12 & 0.84 \\
\hline Energy intake (kJ/day) & $9549.06(8122.15-11,140.99)$ & $9154.93(7714.92-11,087.06)$ & $9221.62(7648.02-11,608.63)$ & 0.35 & 0.35 \\
\hline
\end{tabular}

${ }^{\ddagger}$ Matched variables of the study, ${ }^{\ddagger} p$-value between cancers and controls, ${ }^{\dagger} p$-value between adenomas and controls

Values are presented as median (Q1-Q3) for quantitative variables or $n(\%)$ for qualitative variables

* Significant difference (Mann-Whitney U, $p$-value $<0.05$ ) * Significant difference (Chi-Square, $p$-value $<0.05$ )

$¥$ Comorbidities are defined as diabetes, hypertension and coronary heart disease

MET Metabolic equivalent

[35]. Indeed, disparities between studies could be due to the following reasons: differences in etiology of CRC and responses to diet in men and women, hormone replacement therapy (HRT) and oral contraceptive (OCP) consumption in women which are independently and inversely associated to CRC risk [33, 36] and considering colon and rectum cancer separately or as a single cancer in analyses. Our study agrees with the result of a newly published systematic review and meta-analysis which reported an inverse significant association between higher DASH scores and reduced risks of CRC in both genders [21]. However, risk reduction in our study is far different from previous studies. This difference could represent a random variation, favored by the small sample size of some studies, or could be due to adjustment for different confounders, using self-administered FFQs in some of studies which are prone to self-report bias, whereas we administered face-to face interview by trained interviewers.

The DASH dietary pattern emphasizes the consumption of plant foods. Phytochemical and other antioxidants in these foods exert their anti-tumorigenic characteristics via inhibition of CRC cell growth (suppression of NF- $\mathrm{KB}$ pathway), inducing apoptosis, and reaction with reactive oxygen species [37, 38]. Further, they can interact with CRA and CRC cell growth by blocking the natural cell cycle [39]. Fiber content of plant foods is known to reduce the risk of CRC and CRA by increasing fecal volume, decreasing transit time, and therefore, decreasing the interaction of carcinogen 
Table 2 The main characteristics of the participants according to quartiles of energy-adjusted DASH score

\begin{tabular}{|c|c|c|c|c|c|}
\hline \multirow[t]{3}{*}{ Variables } & \multicolumn{4}{|c|}{ DASH score quartiles } & \multirow[t]{3}{*}{$P$-value ${ }^{*}$} \\
\hline & Quartile 1 & Quartile 2 & Quartile 3 & Quartile 4 & \\
\hline & $\leq 20$ & $21-24$ & $25-28$ & $\geq 29$ & \\
\hline Age $(\text { years })^{\ddagger}$ & $54.29(11.76)$ & $54.19(9.72)$ & $57.19(9.44)$ & $58.19(8.56)$ & 0.002 \\
\hline \multicolumn{6}{|l|}{ Gender ${ }^{\ddagger}$} \\
\hline Woman & $58(41.7)$ & $66(50.4)$ & $62(51.2)$ & $55(50.9)$ & \multirow[t]{2}{*}{0.34} \\
\hline Man & $81(58.3)$ & $65(49.6)$ & $59(48.8)$ & $53(49.1)$ & \\
\hline BMI (kg/m2) & $26.71(4.04)$ & $26.91(5.21)$ & $26.61(4.36)$ & $27.04(3.69)$ & 0.87 \\
\hline Energy intake (kcal) & $2341.1(678.5)$ & 2357.1(681.8) & $2299.1(659.7)$ & $2299.7(552.5)$ & 0.85 \\
\hline Physical activity (MET/day) & $36.82(7.78)$ & $38.62(14.85)$ & $39.86(11.75)$ & $40.24(9.8)$ & 0.07 \\
\hline \multicolumn{6}{|l|}{ Education levels } \\
\hline Illiterate & $20(14.6)$ & $20(15.5)$ & $17(14)$ & $6(5.6)$ & \multirow[t]{3}{*}{0.21} \\
\hline Low & $99(72.3)$ & $91(70.5)$ & 87(71.9) & $80(74.1)$ & \\
\hline High & 18(13.1) & $18(14)$ & $17(14)$ & $22(20.4)$ & \\
\hline Smoking (yes) & $35(25.2)$ & $21(16)$ & $21(17.4)$ & 18(16.7) & 0.32 \\
\hline Comorbidities (yes) ${ }^{¥}$ & $27(19.4)$ & 24(18.3) & $31(25.6)$ & $20(18.5)$ & 0.44 \\
\hline Diabetes (yes) & $10(7.2)$ & 10(7.6) & 13(10.7) & $11(10.2)$ & 0.68 \\
\hline Hypertension (yes) & $12(8.6)$ & $9(6.9)$ & 13(10.7) & $6(5.6)$ & 0.49 \\
\hline Coronary Heart diseases (yes) & $5(3.6)$ & $3(2.3)$ & $7(5.8)$ & $4(3.7)$ & 0.54 \\
\hline Family history of cancer in first degree (yes) & $62(44.6)$ & $50(38.2)$ & $37(30.6)$ & $44(40.7)$ & 0.13 \\
\hline $\begin{array}{l}\text { Colorectal cancer family history in first degree } \\
\text { relatives (yes) }\end{array}$ & $13(9.4)$ & $12(9.2)$ & $9(7.4)$ & 11(10.2) & 0.87 \\
\hline \multicolumn{6}{|l|}{ Level of salt intake } \\
\hline Low & $40(28.8)$ & $58(44.3)$ & $62(51.2)$ & $69(63.9)$ & \\
\hline Normal & $70(50.4)$ & $51(38.9)$ & $49(40.5)$ & $32(29.6)$ & \multirow[t]{2}{*}{0.00} \\
\hline High & 29(20.9) & $22(16.8)$ & 10(8.6) & $7(6.5)$ & \\
\hline Alcohol consumption & $11(7.9)$ & $4(3.1)$ & $4(3.3)$ & $4(3.7)$ & 0.11 \\
\hline Daily intake of multi vitamins and minerals (yes) & $8(5.8)$ & $15(11.5)$ & $7(5.8)$ & $13(12)$ & 0.13 \\
\hline
\end{tabular}

Values are mean (SD) or number (percentage)

${ }^{\ddagger}$ Matched variables of the study, ${ }^{*} p$-value between quartiles of DASH score

Independent sample t-test was used for continuous variables and Chi-square was used for categorical variables. MET: Metabolic equivalent

$¥$ Comorbidities are defined as diabetes, hypertension and coronary heart disease

Table 3 A comparison between the case (Cancer and adenomas) and control groups based on daily intake of the energy-adjusted DASH score components

\begin{tabular}{|c|c|c|c|c|}
\hline DASH score components & $\begin{array}{l}\text { control } \\
(n=240)\end{array}$ & $\begin{array}{l}\text { Colorectal cancer } \\
(n=129)\end{array}$ & $\begin{array}{l}\text { Adenomas } \\
(n=130)\end{array}$ & $p$-value* \\
\hline Energy-adjusted DASH score & $27(23-30)$ & $21(19-24)$ & $22(19.7-26)$ & $<0.001$ \\
\hline Vegetables (serving/1000 kcal) & $1.67(0.84)$ & $1.20(0.49)$ & $1.46(0.82)$ & $<0.001$ \\
\hline Fruits (serving/1000 kcal) & $1.12(0.50)$ & $0.79(0.32)$ & $0.98(0.45)$ & $<0.001$ \\
\hline Whole grains (serving/1000 kcal) & $1.43(1.16)$ & $1.09(0.81)$ & $1.27(1.05)$ & 0.01 \\
\hline Nuts, legumes and seeds (serving/1000 kcal) & $0.55(0.38)$ & $0.47(0.32)$ & $0.50(0.38)$ & 0.09 \\
\hline Low fat dairy (serving/1000 kcal) & $0.73(0.44)$ & $0.75(0.47)$ & $0.75(0.44)$ & 0.91 \\
\hline Red and processed meats (serving/1000 kcal) & $0.29(0.20)$ & $0.59(0.39)$ & $0.47(0.30)$ & $<0.001$ \\
\hline Sweetened beverages (serving/1000 kcal) & $0.06(0.12)$ & $0.08(0.12)$ & $0.10(0.15)$ & 0.01 \\
\hline Sodium (g/d) & $1857.1(512.5)$ & $2155.69(579.1)$ & 2149.2(587.6) & $<0.001$ \\
\hline
\end{tabular}

Values are mean (SD) or median (IQR)

* P-value estimated using ANOVA or Kruskal-wllis test 
Table 4 OR and 95\% confidence interval for risk of colorectal cancer, adenoma and colorectal cancer plus adenoma based on quartile of energy-adjusted DASH score

\begin{tabular}{|c|c|c|c|c|c|}
\hline Dietary DASH score & $\begin{array}{l}\text { Quartile1 } \\
\leq 20\end{array}$ & $\begin{array}{l}\text { Quartile2 } \\
21-24\end{array}$ & $\begin{array}{l}\text { Quartile3 } \\
25-28\end{array}$ & $\begin{array}{l}\text { Quartile4 } \\
\geq 29\end{array}$ & P for trend \\
\hline \multicolumn{6}{|l|}{ Colorectal cancer } \\
\hline \multicolumn{6}{|l|}{ Women } \\
\hline Case (control) & $19(14)$ & $23(23)$ & $16(28)$ & $5(42)$ & \\
\hline Crude OR (95\% Cl) & 1.00 & $0.73(0.29-1.81)$ & $0.42(0.16-1.06)$ & $0.08(0.02-0.27)$ & $<0.001$ \\
\hline Adjusted OR* $(95 \% \mathrm{Cl})$ & 1.00 & 0.76(0.29-1.97) & $0.42(0.16-1.11)$ & $0.07(0.02-0.24)$ & $<0.001$ \\
\hline Adjusted $\mathrm{OR}^{* *}(95 \% \mathrm{Cl})$ & 1.00 & $0.89(0.31-2.54)$ & $0.42(0.14-1.24)$ & $0.07(0.02-0.26)$ & $<0.001$ \\
\hline \multicolumn{6}{|l|}{ Men } \\
\hline Case (control) & $37(22)$ & $22(26)$ & $5(40)$ & $2(45)$ & \\
\hline Crude OR (95\% Cl) & 1.00 & $0.50(0.23-1.09)$ & $0.07(0.02-0.21)$ & $0.02(0.00-0.12)$ & $<0.001$ \\
\hline Adjusted OR* $(95 \% \mathrm{Cl})$ & 1.00 & $0.47(0.21-1.06)$ & $0.06(0.02-0.18)$ & $0.02(0.00-0.10)$ & $<0.001$ \\
\hline Adjusted $\mathrm{OR}^{* *}(95 \% \mathrm{Cl})$ & 1.00 & $0.63(0.26-1.48)$ & $0.07(0.02-0.24)$ & $0.02(0.00-0.13)$ & $<0.001$ \\
\hline \multicolumn{6}{|l|}{ Pooled } \\
\hline Case (control) & $56(36)$ & $45(49)$ & $21(68)$ & $7(87)$ & \\
\hline Crude OR (95\% Cl) & 1.00 & $0.59(0.33-1.05)$ & $0.19(0.10-0.37)$ & $0.05(0.02-0.12)$ & $<0.001$ \\
\hline Adjusted OR* $(95 \% \mathrm{Cl})$ & 1.00 & $0.57(0.31-1.04)$ & $0.17(0.09-0.34)$ & $0.04(0.01-0.10)$ & $<0.001$ \\
\hline Adjusted $\mathrm{OR}^{* *}(95 \% \mathrm{Cl})$ & 1.00 & $0.69(0.36-1.31)$ & $0.22(0.11-0.44)$ & $0.04(0.01-0.11)$ & $<0.001$ \\
\hline \multicolumn{6}{|l|}{ Adenoma } \\
\hline \multicolumn{6}{|l|}{ Women } \\
\hline Case (control) & $25(14)$ & $20(23)$ & $18(28)$ & $8(42)$ & \\
\hline Crude OR (95\% Cl) & 1.00 & $0.58(0.28-1.21)$ & $0.38(0.18-0.79)$ & $0.13(0.05-0.32)$ & $<0.001$ \\
\hline Adjusted OR* $(95 \% \mathrm{Cl})$ & 1.00 & $0.57(0.27-1.19)$ & $0.32(0.15-0.68)$ & $0.04(0.04-0.27)$ & $<0.001$ \\
\hline Adjusted OR**(95\% Cl) & 1.00 & $0.42(0.16-1.12)$ & $0.25(0.09-0.69)$ & $0.06(0.02-0.20)$ & $<0.001$ \\
\hline \multicolumn{6}{|l|}{ Men } \\
\hline Case (control) & $22(22)$ & $17(26)$ & $14(40)$ & $6(45)$ & \\
\hline Crude OR (95\% Cl) & 1.00 & $0.56(0.26-1.22)$ & $0.33(0.15-0.73)$ & $0.11(0.04-0.30)$ & $<0.001$ \\
\hline Adjusted $\mathrm{OR}^{*}(95 \% \mathrm{Cl})$ & 1.00 & $0.65(0.27-1.53)$ & $0.35(0.15-0.81)$ & $0.13(0.04-0.37)$ & $<0.001$ \\
\hline Adjusted $\mathrm{OR}^{* *}(95 \% \mathrm{Cl})$ & 1.00 & $0.68(0.26-1.72)$ & $0.30(0.11-0.80)$ & $0.14(0.04-0.44)$ & $<0.001$ \\
\hline \multicolumn{6}{|l|}{ Pooled } \\
\hline Case (control) & $47(36)$ & $37(49)$ & $32(68)$ & $14(87)$ & \\
\hline Crude OR (95\% Cl) & 1.00 & $0.57(0.37-1.06)$ & $0.36(0.19-0.66)$ & $0.12(0.06-0.25)$ & $<0.001$ \\
\hline Adjusted $\mathrm{OR}^{*}(95 \% \mathrm{Cl})$ & 1.00 & $0.57(0.31-1.07)$ & $0.30(0.16-0.57)$ & $0.10(0.04-0.21)$ & $<0.001$ \\
\hline Adjusted $\mathrm{OR}^{* *}(95 \% \mathrm{Cl})$ & 1.00 & $0.60(0.31-1.15)$ & $0.31(0.16-0.61)$ & $0.10(0.04-0.22)$ & $<0.001$ \\
\hline \multicolumn{6}{|c|}{ Colorectal cancer plus Adenoma } \\
\hline \multicolumn{6}{|l|}{ Women } \\
\hline Case (control) & $44(14)$ & $43(23)$ & $34(28)$ & $13(42)$ & $<0.001$ \\
\hline Crude OR (95\% CI) & 1.00 & $0.59(0.27-1.30)$ & $0.38(0.17-0.84)$ & $0.09(0.04-0.23)$ & $<0.001$ \\
\hline Adjusted OR* $(95 \% \mathrm{Cl})$ & 1.00 & $0.55(0.24-1.24)$ & $0.34(0.15-0.77)$ & $0.08(0.03-0.20)$ & $<0.001$ \\
\hline Adjusted $\mathrm{OR}^{* *}(95 \% \mathrm{Cl})$ & 1.00 & $0.59(0.25-1.39)$ & $0.35(0.15-0.83)$ & $0.07(0.02-0.18)$ & \\
\hline \multicolumn{6}{|l|}{ Men } \\
\hline Case (control) & $59(22)$ & $39(26)$ & $19(40)$ & $8(45)$ & $<0.001$ \\
\hline Crude OR (95\% Cl) & 1.00 & $0.55(0.27-1.12)$ & $0.17(0.08-0.36)$ & $0.06(0.02-0.16)$ & 0.03 \\
\hline Adjusted OR* $(95 \% \mathrm{Cl})$ & 1.00 & $0.55(0.27-1.12)$ & $0.15(0.07-0.33)$ & $0.05(0.02-0.14)$ & $<0.001$ \\
\hline Adjusted $\mathrm{OR}^{* *}(95 \% \mathrm{Cl})$ & 1.00 & $0.64(0.30-1.35)$ & $0.16(0.07-0.37)$ & $0.06(0.02-0.16)$ & \\
\hline
\end{tabular}


Table 4 OR and 95\% confidence interval for risk of colorectal cancer, adenoma and colorectal cancer plus adenoma based on quartile of energy-adjusted DASH score (Continued)

\begin{tabular}{llllll}
\hline Dietary DASH score & $\begin{array}{l}\text { Quartile1 } \\
\leq \mathbf{2 0}\end{array}$ & $\begin{array}{l}\text { Quartile2 } \\
\mathbf{2 1 - 2 4}\end{array}$ & $\begin{array}{l}\text { Quartile3 } \\
\mathbf{2 5 - 2 8}\end{array}$ & $\begin{array}{l}\text { Quartile4 } \\
\geq 29\end{array}$ & $\begin{array}{l}\text { P for trend } \\
\text { Pooled }\end{array}$ \\
$\quad 103(36)$ & $82(49)$ & $53(68)$ & $21(87)$ & $<0.001$ \\
$\quad$ Case (control) & 1.00 & $0.58(0.34-0.98)$ & $0.27(0.16-0.45)$ & $0.08(0.04-0.15)$ & $<0.001$ \\
$\quad$ Crude OR $(95 \% \mathrm{Cl})$ & 1.00 & $0.56(0.33-0.95)$ & $0.24(0.14-0.41)$ & $0.07(0.03-0.13)$ & $<0.001$ \\
$\quad$ Adjusted OR* $(95 \% \mathrm{Cl})$ & 1.00 & $0.64(0.37-1.10)$ & $0.26(0.10-0.47)$ & $0.07(0.03-0.14)$ & \\
$\quad$ Adjusted OR** $(95 \% \mathrm{Cl})$ & & & & & \\
\hline
\end{tabular}

*Model 1: Adjusted for age (year)

**Model 2: Adjusted for BMI $\left(\mathrm{kg} / \mathrm{m}^{2}\right)$, age (year), alcohol consumption, physical activity (MET), history of diabetes, CHD and hypertension, family history of cancer

with colonic epithelium, production of short chain fatty acids, and insulin resistance $[40,41]$. The DASH dietary pattern is also low in red and processed meat; indeed, the high fat content of red meat, and heterocyclic amines and polycyclic aromatic hydrocarbons produced from cocking meat at high temperatures, in addition to nitrosyl-heme molecules in processed meats that result in N-nitroso compounds formation, are associated with increased risk of CRC and CRA [42, 43]. The DASH diet also advocates lower intakes of sugar-sweetened beverages; although the relationship between such beverages and CRC and CRA has not been fully confirmed, hyperinsulinemia and increased insulin growth factor-1 (IGF-1) consequential to consumption of these drinks can effect on carcinogenesis and conversion of adenomas to malignancies through crucial pathways, such as mitogen-activated protein kinase (MAPK) pathway and phosphoinositide 3-kinase (PI3K) pathway [44-46]. An important feature of the DASH diet is low sodium intake; accordingly, results of studies on the association of sodium and higher risk of CRC are not particularly strong, but some studies have reported positive associations between sodium and CRC risk [47]. Indeed, considering the synergic interaction between components of the DASH dietary pattern and CRC and CRA, rather than individual components, can be helpful in providing public messages to reduce the risk of CRC, and CRA as a precursor of CRC.

Although this study presents an important and novel addition to the literature, there are some limitations that should be considered. First, recall and selection bias cannot be avoided in case-control studies; however, we sought to minimize such biases by recruiting incident cases along with hospital controls. Second, we did not have information about HRT and OCP use in women, so the results could be affected by them, and they should be considered as potentially confounding variables in future work. Another limitation of our study is that although sample size is not low, when we classified participants according to various factors, the number of people decreased in each quartile. Concomitant to the aforementioned limitations, our study has some strengths that are noteworthy. First, to our knowledge, this is the first study on the association of DASH diet score and the risk of CRC and CRA in Iran, and in the Middle East. Second, we used Fung's method to calculate DASH score, which includes wider ranges of possible scores (1 through 5 ), while some scores, such as Dixon's, have only two values for components ( 0 for not meeting and 1 for meeting recommendations) [23]. Third, we used a validated FFQ, administered by trained nutritionists, to more accurately estimate the main exposure [27].

\section{Conclusion}

In conclusion, the results of this study demonstrated that adherence to a DASH dietary pattern could reduce the risk of colorectal cancer and colorectal adenomas in men and women. Moreover, promoting a DASH eating plan, as a balanced and healthy diet, in dietary guidelines could be helpful in reducing the risk of CRC in lessdeveloped countries.

\section{Abbreviations}

CRC: Colorectal cancer; CRAs: Colorectal adenomas; DASH: Dietary Approaches to Stop Hypertension; IBD: Inflammatory bowel diseases; USDA: United States Department of Agriculture; ANOVA: Analysis of variance; MET: Physical activity; CHD: Coronary heart disease; ORs: Odds ratios; HRT: Hormone replacement therapy; OCP: Oral contraceptive; IGF-1: Insulin growth factor-1; MAPK: Mitogen-activated protein kinase;

PI3K: Phosphoinositide 3-kinase.

\section{Acknowledgements \\ The authors thank all study participants, without whom, the current study would have been impossible.}

\section{Authors' contributions}

Formal analysis: MG and SJN, Investigation: SJN, NM, PR and AB, Resources: $A S$ and $M H$, Writing: SJN, MG and EH, Review and editing: $C C C$ and $E H$, Visualization: EH and AS, Supervision: EH. All authors read and approved the final manuscript.

\section{Funding}

This study has not receive funds from organization and people.

\section{Availability of data and materials}

The datasets used and/or analysed during the current study are available from the corresponding and first author on reasonable request. 


\section{Declarations}

\section{Ethics approval and consent to participate}

Informed consent was provided by all of the participant indicating they participated in this study by their own will and they were informed that results would be published later.

This study was conducted according to the guidelines laid down in the Declaration of Helsinki and all procedures involving research study participants were approved by the ethics Committee of Shahid Beheshti University of Medical Sciences

\section{Consent for publication} NOT APPLICABLE.

\section{Competing interests}

The authors declare that they have no competing interests.

\begin{abstract}
Author details
'Student Research Committee, School of Nutrition and Food Science, Isfahan University of Medical Sciences, Isfahan, Iran. ${ }^{2}$ Department of Clinical Nutrition and Dietetics, Faculty of Nutrition Sciences and Food Technology, National Nutrition and Food Technology, Research Institute, Shahid Beheshti University of Medical Sciences, Tehran, Iran. ${ }^{3}$ Department of Nutrition, Islamic Azad University, Science and Research Branch, Tehran, Iran. ${ }^{4}$ Centre for Intelligent Healthcare, Coventry University, Coventry CV15FB, UK.

${ }^{5}$ Gastroenterology and Liver Diseases Research Center, Research Institute for Gastroenterology and Liver Diseases, Shahid Beheshti University of Medical Sciences, Tehran, Iran. ${ }^{6}$ Department of Radiation Oncology, Faculty of Medicine, Shahid Beheshti University of Medical Sciences, Tehran, Iran.
\end{abstract}

\section{Received: 21 January 2021 Accepted: 9 September 2021}

\section{Published online: 25 September 2021}

\section{References}

1. Torre LA, Bray F, Siegel RL, Ferlay J, Lortet-Tieulent J, Jemal A. Global cancer statistics, 2012. CA Cancer J Clin. 2015;65(2):87-108. https://doi.org/10.3322/ caac.21262.

2. Khosravi Shadmani F, Ayubi E, Khazaei S, Sani M, Mansouri Hanis S, Khazaei $\mathrm{S}$, et al. Geographic distribution of the incidence of colorectal cancer in Iran: a population-based study. Epidemiol Health. 2017;39:e2017020-e2017020. https://doi.org/10.4178/epih.e2017020.

3. Dolatkhah R, Somi MH, Kermani IA, Ghojazadeh M, Jafarabadi MA, Farassati $F$, et al. Increased colorectal cancer incidence in Iran: a systematic review and meta-analysis. BMC Public Health. 2015;15(1):997-997. https://doi.org/1 0.1186/s12889-015-2342-9.

4. Haggar FA, Boushey RP. Colorectal cancer epidemiology: incidence, mortality, survival, and risk factors. Clin Colon Rectal Surg. 2009;22(4):191-7. https://doi.org/10.1055/s-0029-1242458.

5. Kuipers EJ, Grady WM, Lieberman D, Seufferlein T, Sung JJ, Boelens PG, et al. Colorectal cancer. Nat Rev Dis Primers. 2015;1(1):15065-15065. https://doi. org/10.1038/nrdp.2015.65.

6. Giovannucci E, Stampfer MJ, Colditz G, Rimm EB, Willett WC. Relationship of diet to risk of colorectal adenoma in men. J Natl Cancer Inst. 1992;84(2):918. https://doi.org/10.1093/jnci/84.2.91

7. Baena R, Salinas P. Diet and colorectal cancer. Maturitas. 2015;80(3):258-64 https://doi.org/10.1016/..maturitas.2014.12.017.

8. Nguyen S, Li H, Yu D, Gao J, Gao Y, Tran H, et al. Adherence to dietary recommendations and colorectal cancer risk: results from two prospective cohort studies. Int J Epidemiol. 2019;49(1):270-80. https://doi.org/10.1093/ ije/dyz118.

9. Kushi LH, Doyle C, McCullough M, Rock CL, Demark-Wahnefried W, Bandera $\mathrm{EV}$, et al. American Cancer Society guidelines on nutrition and physical activity for cancer prevention: reducing the risk of cancer with healthy food choices and physical activity. CA Cancer J Clin. 2012;62(1):30-67. https://doi. org/10.3322/caac.20140.

10. Onvani S, Haghighatdoost F, Surkan PJ, Larijani B, Azadbakht L. Adherence to the healthy eating index and alternative healthy eating index dietary patterns and mortality from all causes, cardiovascular disease and cancer: a meta-analysis of observational studies. J Hum Nutr Diet. 2017;30(2):216-26. https://doi.org/10.1111/jhn.12415.
11. Rumawas ME, Dwyer JT, McKeown NM, Meigs JB, Rogers G, Jacques PF. The development of the Mediterranean-style dietary pattern score and its application to the American diet in the Framingham offspring cohort. J Nutr. 2009;139(6):1150-6. https://doi.org/10.3945/jn.108.103424.

12. Vogt TM, Appel LJ, Obarzanek E, Moore TJ, Vollmer WM, Svetkey LP, et al. Dietary approaches to stop hypertension: rationale, design, and methods. DASH collaborative research group. J Am Diet Assoc. 1999;99(8 Suppl):S128. https://doi.org/10.1016/S0002-8223(99)00411-3.

13. Harnden KE, Frayn KN, Hodson L. Dietary approaches to stop hypertension (DASH) diet: applicability and acceptability to a UK population. J Hum Nutr Diet. 2010;23(1):3-10. https://doi.org/10.1111/j.1365-277X.2009.01007.x.

14. Mohseni R, Mohseni F, Alizadeh S, Abbasi S. The Association of Dietary Approaches to stop hypertension (DASH) diet with the risk of colorectal Cancer: a Meta-analysis of observational studies. Nutr Cancer. 2020;72(5): 778-90. https://doi.org/10.1080/01635581.2019.1651880.

15. Ali Mohsenpour M, Fallah-Moshkani R, Ghiasvand R, Khosravi-Boroujeni H, Mehdi Ahmadi S, Brauer P. Adherence to Dietary Approaches to Stop Hypertension (DASH)-Style Diet and the Risk of Cancer: A Systematic Review and Meta-Analysis of Cohort. Studies. 2019;38(6):513-25. https://doi.org/10.1 080/07315724.2018.1554460

16. Ghorabi S, Salari-Moghaddam A, Daneshzad E, Sadeghi O, Azadbakht L, Djafarian K. Association between the DASH diet and metabolic syndrome components in Iranian adults. Diabetes Metab Syndr. 2019;13(3):1699-704. https://doi.org/10.1016/j.dsx.2019.03.039.

17. Zhao Z, Yin Z, Hang Z, Zhang C, Zhao Q. Association between red and processed meat intake and colorectal adenoma incidence and recurrence: a systematic review and meta-analysis. Oncotarget. 2018;9(64):32373-82. https://doi.org/10.18632/oncotarget.23561.

18. Onvani S, Haghighatdoost F, Azadbakht L. Dietary approach to stop hypertension (DASH): diet components may be related to lower prevalence of different kinds of cancer: a review on the related documents. J Res Med Sci. 2015;20(7):707-13. https://doi.org/10.4103/1735-1995.166233.

19. Nagata C, Shimizu H, Kametani M, Takeyama N, Ohnuma T, Matsushita S. Diet and colorectal adenoma in Japanese males and females. Dis Colon Rectum. 2001;44(1):105-11. https://doi.org/10.1007/BF02234831.

20. Wang Z, Uchida K, Ohnaka K, Morita M, Toyomura K, Kono S, et al. Sugars, sucrose and colorectal cancer risk: the Fukuoka colorectal cancer study. Scand J Gastroenterol. 2014;49(5):581-8. https://doi.org/10.3109/00365521.2013.822091.

21. Tangestani H, Salari-Moghaddam A, Ghalandari H, Emamat H. Adherence to the dietary approaches to stop hypertension (DASH) dietary pattern reduces the risk of colorectal cancer: a systematic review and meta-analysis. Clin Nutr. 2020;39(10):2975-81. https://doi.org/10.1016/..Inu.2020.02.002.

22. Fung TT, Hu FB, Wu K, Chiuve SE, Fuchs CS, Giovannucci E. The Mediterranean and dietary approaches to stop hypertension (DASH) diets and colorectal cancer. Am J Clin Nutr. 2010;92(6):1429-35. https://doi.org/1 0.3945/ajen.2010.29242.

23. Miller PE, Cross AJ, Subar AF, Krebs-Smith SM, Park Y, Powell-Wiley T, et al. Comparison of 4 established DASH diet indexes: examining associations of index scores and colorectal cancer. Am J Clin Nutr. 2013;98(3):794-803. https://doi.org/10.3945/ajcn.113.063602.

24. Dixon LB, Subar AF, Peters U, Weissfeld JL, Bresalier RS, Risch A, et al. Adherence to the USDA food guide, DASH eating plan, and Mediterranean dietary pattern reduces risk of colorectal adenoma. J Nutr. 2007:137(11): 2443-50. https://doi.org/10.1093/jn/137.11.2443.

25. Erben V, Carr PR, Holleczek B, Stegmaier C, Hoffmeister M, Brenner $\mathrm{H}$. Dietary patterns and risk of advanced colorectal neoplasms: a large population based screening study in Germany. Prev Med. 2018;111:101-9. https://doi.org/10.1016/j.ypmed.2018.02.025.

26. Jafari Nasab S, Bahrami A, Rafiee P, Hekmatdoust A, Ghanavati M, Rashidkhani B, et al. Healthy eating Index-2010 and Mediterranean-style dietary pattern score and the risk of colorectal cancer and adenoma: a case-control study. Nutr Cancer. 2020;72(8):1326-35. https://doi.org/10.1 080/01635581.2019.1683212.

27. Asghari G, Rezazadeh A, Hosseini-Esfahani F, Mehrabi Y, Mirmiran P, Azizi F. Reliability, comparative validity and stability of dietary patterns derived from an FFQ in the Tehran lipid and glucose study. Br J Nutr. 2012;108(6):110917. https://doi.org/10.1017/S0007114511006313.

28. Azar M, Sarkisian E. Food composition table of Iran. Tehran: National Nutrition and Food Research Institute, Shaheed Beheshti University. 1980;65.

29. Fung TT, Chiuve SE, McCullough ML, Rexrode KM, Logroscino G, Hu FB. Adherence to a DASH-style diet and risk of coronary heart disease and 
stroke in women. Arch Intern Med. 2008;168(7):713-20. https://doi.org/10.1 001/archinte.168.7.713.

30. Aadahl M, Jørgensen T. Validation of a new self-report instrument for measuring physical activity. Med Sci Sports Exerc. 2003;35(7):1196-202. https://doi.org/10.1249/01.MSS.0000074446.02192.14.

31. Park S-Y, Boushey CJ, Wilkens LR, Haiman CA, Le Marchand L. High-Quality Diets Associate With Reduced Risk of Colorectal Cancer: Analyses of Diet Quality Indexes in the Multiethnic Cohort. Gastroenterology. 2017;153(2):386-394.e382.

32. Petimar J, Smith-Warner SA, Fung TT, Rosner B, Chan AT, Hu FB, et al. Recommendation-based dietary indexes and risk of colorectal cancer in the Nurses' health study and health professionals follow-up study. Am J Clin Nutr. 2018;108(5):1092-103. https://doi.org/10.1093/ajcn/nqy171.

33. Jones-McLean E, Hu J, Greene-Finestone LS, de Groh M. A DASH dietary pattern and the risk of colorectal cancer in Canadian adults. Health Promot Chronic Dis Prev Can. 2015:35(1):12-20. https://doi.org/10.24095/hpcdp.35.1.03.

34. Torres Stone RA, Waring ME, Cutrona SL, Kiefe Cl, Allison J, Doubeni CA. The association of dietary quality with colorectal cancer among normal weight, overweight and obese men and women: a prospective longitudinal study in the USA. BMJ Open. 2017;7(6):e015619-e015619. https://doi.org/10.1136/ bmjopen-2016-015619.

35. Vargas AJ, Neuhouser ML, George SM, Thomson CA, Ho GYF, Rohan TE, et al. Diet quality and colorectal Cancer risk in the Women's Health Initiative observational study. Am J Epidemiol. 2016;184(1):23-32. https://doi.org/10.1 093/aje/kwv304.

36. Reedy J, Mitrou P, Krebs-Smith S, Wirfält E, Flood A, Kipnis V, et al. Index-based dietary patterns and risk of colorectal cancer: the $\mathrm{NH}$-AARP diet and health study. Am J Epidemiol. 2008;168(1):38-48. https://doi.org/10.1093/aje/kwn097.

37. Lü JM, Lin PH, Yao Q, Chen C. Chemical and molecular mechanisms of antioxidants: experimental approaches and model systems. J Cell Mol Med. 2010;14(4):840-60. https://doi.org/10.1111/j.1582-4934.2009.00897.x.

38. Li YH, Niu YB, Sun Y, Zhang F, Liu CX, Fan L, et al. Role of phytochemicals in colorectal cancer prevention. World J Gastroenterol. 2015;21(31):9262-72. https://doi.org/10.3748/wjg.v21.i31.9262

39. Jaganathan SK, Vellayappan MV, Narasimhan G, Supriyanto E, Dewi DEO, Narayanan ALT, et al. Chemopreventive effect of apple and berry fruits against colon cancer. World J Gastroenterol: WJG. 2014;20(45):17029-36. https://doi.org/10.3748/wjg.v20.i45.17029.

40. Kunzmann AT, Coleman HG, Huang W-Y, Kitahara CM, Cantwell MM, Berndt SI. Dietary fiber intake and risk of colorectal cancer and incident and recurrent adenoma in the prostate, lung, colorectal, and ovarian Cancer screening trial. Am J Clin Nutr. 2015;102(4):881-90. https:/doi.org/10.3945/ajcn.115.113282.

41. Aune D, Chan DS, Lau R, Vieira R, Greenwood DC, Kampman E, et al. Dietary fibre, whole grains, and risk of colorectal cancer: systematic review and dose-response meta-analysis of prospective studies. BMJ. 2011;343:d6617. https://doi.org/10.1136/bmj.d6617.

42. Demeyer D, Mertens B, De Smet S, Ulens M. Mechanisms linking colorectal Cancer to the consumption of (processed) red meat: a review. Crit Rev Food Sci Nutr. 2016;56(16):2747-66. https://doi.org/10.1080/10408398.2013.873886.

43. Chiavarini M, Bertarelli G, Minelli L, Fabiani R. Dietary intake of meat cooking-related mutagens (HCAs) and risk of colorectal adenoma and Cancer: a systematic review and Meta-analysis. Nutrients. 2017;9(5):514. https://doi.org/10.3390/nu9050514.

44. Cho H, Budhathoki S, Kanehara R, Goto A, Yamaji T, Kakugawa Y, et al. Association between dietary sugar intake and colorectal adenoma among cancer screening examinees in Japan. Cancer Sci. 2020;111(10):3862-72. https://doi.org/10.1111/cas.14596.

45. Pacheco LS, Anderson CAM, Lacey JV Jr, Giovannucci EL, Lemus H, Araneta MRG, et al. Sugar-sweetened beverages and colorectal cancer risk in the California teachers study. PLoS One. 2019;14(10):e0223638. https://doi.org/1 0.1371/journal.pone.0223638.

46. Zhang R, Xu G-L, Li Y, He L-J, Chen L-M, Wang G-B, et al. The role of insulinlike growth factor 1 and its receptor in the formation and development of colorectal carcinoma. J Int Med Res. 2013;41(4):1228-35. https://doi.org/1 $0.1177 / 0300060513487631$

47. Yakoob MY, Baig-ansari N. Dietary Sodium (salt) Intake and Risk of Colorectal Cancer: A Systematic Review (P05-039-19). Curr Dev Nutr. 2019;3(9). https:// doi.org/10.1093/cdn/nzz098.

\section{Publisher's Note}

Springer Nature remains neutral with regard to jurisdictional claims in published maps and institutional affiliations.

Ready to submit your research? Choose BMC and benefit from:

- fast, convenient online submission

- thorough peer review by experienced researchers in your field

- rapid publication on acceptance

- support for research data, including large and complex data types

- gold Open Access which fosters wider collaboration and increased citations

- maximum visibility for your research: over $100 \mathrm{M}$ website views per year

At $\mathrm{BMC}$, research is always in progress.

Learn more biomedcentral.com/submissions 